\title{
Empirical Paper
}

\section{Elżbieta Wąsowicz-Zaborek* \\ Antecedents of loyalty intentions among young adult tourists: a survey}

https://doi.org/10.2478/ijme-2019-0021

Received August 01, 2019; accepted November 14, 2019

\begin{abstract}
The purpose of this paper was to examine the antecedents of young adult tourists' loyalty intentions. The study is concerned with the overall loyalty tendencies of individuals, comprising the two dimensions of revisit intentions (RVIs) and recommendation intentions (RIs), and thus does not explore their loyalty to a specific destination (as in most previous studies). The research uses an Internet questionnaire with a total sample of 305 university students recruited from two Polish universities. Statistical analysis with the partial least squares structural equation modeling method indicates that destination RI is mainly driven by social bonding, while RVI is influenced positively by risk and uncertainty avoidance and negatively by novelty and variety seeking. In addition, income is found to be a significant moderator in the relationship between risk and uncertainty perception and RIs, such that a transition from very low to very high incomes tends to reverse the focal relationship from positive to negative. In addition, the research demonstrates that there is no significant difference between male and female young tourist's loyalty intention. Implications for tourism entrepreneurs and destinations are suggested in the concluding section of the article.
\end{abstract}

Keywords: loyalty in tourism, destination loyalty, recommendation intention, revisit intention, PLS-SEM JEL Classification: Z32, Z33, M31

\section{Introduction}

One of the attributes of tourism demand is its restitution [Dziedzic and Skalska, 2012], caused by the constant renewal of tourists' needs. An emerging tourist need may be associated with a desire to repeat a similar trip or may manifest itself in a preference to visit the same location but in a different form or for a different purpose (e.g. different accommodation, meals, different trip organization). Given how widespread this phenomenon is, the issue of loyalty and its determinants becomes particularly relevant in the tourism sector.

Customer loyalty is a broad and complex concept. It refers to the overall behavior towards a specific offer, company, product, facility, institution, person or place. Oliver [1997] believes that full loyalty occurs when a customer is deeply convinced that he will buy a particular product again in the future and recommend it, regardless of the market conditions and other contextual factors that may cause a change in their behavior.

Seweryn [2012] pointed out that current trends in consumption (hedonism, sublimation, and individualism) may result in a lower inclination to stay loyal. All manifestations of loyalty behavior can have a positive impact and bring benefits to vendors [Reichheld et al., 2000]. Retaining existing customers may be cheaper than acquiring new ones [Fornell and Wernerfelt, 1987]. Loyal customers are also more likely to share positive information about the product with their friends, relatives, and other potential consumers [Foscht et al., 2009]. Meleddu et al. [2015] indicated that the tendency to recommend a tourist product is a result of being satisfied with staying at a destination. At the same time, different elements of

*Corresponding author: Elżbieta Wąsowicz-Zaborek, Collegium of World Economy, SGH Warsaw School of Economics

E-mail: ewasowi@sgh.waw.pl 
the destination offer may diversely affect the level of satisfaction, and consequently revisit intention (RVI) and share positive information. Therefore, understanding the reasons for tourist loyalty to destinations may help regions and locations compete in an increasingly challenging market [Chen and Gursoy, 2001].

One of the factors differentiating loyalty behavior in tourism may be the age of travelers. Members of different generations tend to demonstrate different willingness to return to places already visited. In this article, the preferences of young adults - the so-called Generation $Y$ - will be investigated.

The manuscript presents the results of the author's own research conducted on a sample of young adults. Constructed on the basis of a literature review, concepts used in the research tool allowed for the estimation of a structural model showing the relationships that exist between the novelty and variety seeking (NVS), uncertainty and risk perception, social bonding (SB), and loyalty inclination expressed through its two dimensions: RVI and intention to recommend the destination.

\section{Literature review and hypotheses}

\subsection{Research gap identification}

Loyalty is a multi-dimensional concept, and many authors present different approaches to defining its dimensions. Proponents of a one-dimensional approach focus mainly on the volume and repetition of purchases or repeat buying intention [Farley, 1964; Sheth, 1968; McConnell, 1968], which underscores the behavioral facet of the concept.

In contrast, Worthington et al. [2009] considered loyalty as a three-dimensional phenomenon encompassing three aspects:

- cognitive (cognitive), related to the evaluation of the features of an offer,

- affective, relating to the emotions that the product evokes,

- behavioral, as an intention to:

- buy the same product again,

- buy a greater quantity of the same product, and

- give a positive opinion about the product.

Accordingly, achieving loyalty in the cognitive, affective, and behavioral sense induces lower sensitivity to competitors' actions and leads to many top- and bottom-line benefits for the company [Strum and Thiry, 1991] .

Yet another popular perspective identifies two basic dimensions to loyalty: attitudinal and behavioral [Day, 1969], which are also what the author adopted for the current study. The attitudinal dimension views loyalty in terms of consumers' strength of affection toward a brand [Backman and Crompton, 1991]. When comparing the two- and three-dimensional conceptualizations of loyalty, one can observe that cognitive and affective dimensions can be combined with repurchase intentions to form the attitudinal dimension, while all factual actions are classified as behavioral. Attitudinal loyalty can be measured with product preferences, buying intentions, supplier preferences, and willingness to recommend. Behavioral loyalty is usually operationalized as the frequency and quantity of the repurchase of a product, sometimes supplemented by metrics of other purchasing patterns. Many researches accommodate behavioral and attitudinal aspects of loyalty by using a composite definition of customer loyalty, which is a combination of both [Jacoby and Kyner, 1973; Backman and Crompton, 1991; Oliver, 1999; Chen and Tsai, 2007].

Even though there is lack of research comparing tourists across generations, age is a frequently controlled demographical variable, as individuals of various ages might show differences in loyalty to a tourist destination. There is evidence that older customers ( $>50$ years) tend to be more satisfied and more loyal than their younger counterparts [Hsu, 2000], but some studies do not show any meaningful agerelated differences [Chi, 2011]. The current study focuses on the generation of young adults, who, unlike their predecessors, grew up in the age of ubiquitous information and progressive globalization. They have always been accompanied by almost unlimited opportunities to travel and knowledge acquisition and also by an unprecedented variety of options for destinations and travel arrangements. 
Generation Y, also known as the Millennials, is broadly defined as those born between 1980 and 2000 [Richard K. Miller and Associates, 2011]. However, there is no commonly accepted consensus and different authors might use dissimilar timeframes, e.g. 1977-1994 [New Strategist, 2004] or 1982-2005 [Howe and Strauss, 2007].

In Poland, Generation Y is often defined as people of the demographic boom, born in the second part of the 1980s and in the 1990s [Gołąb-Andrzejak, 2014]. Similarly, in this research, the time horizon was set at 1986-2000 and the Millennials aged 18-32 years old were studied.

Members of Generation Y are characterized as [Moscardo and Benckendorff, 2010; Gołąb-Andrzejak, 2016]:

- being well informed about current affairs and trends through their intense use of electronic media,

- using the Internet for shopping,

- looking for shopping deals,

- having relatively low awareness and skills in financial planning,

- inclined to extend adolescence with a longer period of formal education,

- having a positive attitude toward diversity, flexibility, social issues, and the future, and

- oriented toward family and their close social groups (friends and acquaintances).

It is important to note that the profile of people born at any given time is determined by the changes in the macro environment. The Polish Generation Y does not remember the times of the People's Republic of Poland. They grew up in the free market economy with the possibility of traveling without limitations. Sustained rapid economic development has also removed many economic barriers. Therefore, travel is an important part of the leisure time activities of the young adult Poles.

There is a dearth of studies on the tourist loyalty behavior of Generation Y. Most researchers investigating loyalty concentrate on frequency of travel [Richards, 2007], travel motivation [Todorović and Jovičić, 2016], or the modes of tour organization and realization [Kowalczyk-Aniol, 2012]. Those who have investigated RVIs studied mainly travel motivations and satisfaction from previous visits [Kozak and Rimmington, 2000; Bigne et al., 2001; Bowen, 2001; Kozak, 2001; Um et al., 2006; Huang and Hsu, 2009; Ramseook-Munhurrun et al., 2015]. As was already mentioned, the overwhelming majority of authors explored loyalty intentions or loyalty behavior in the context of specific, explicitly defined destinations, which lowered validity of any general conclusions about drivers of loyalty [George and George, 2004; Yoon and Uysal, 2005; Chen and Tsai, 2007; Kim and Brown, 2012; Assaker and Hallak, 2013; Artuger and Cetinsoz, 2017] and on Polish tourist market [Seweryn, 2010]. The current study, by measuring overall loyalty intentions separately from any particular place, attempts to provide insights into general loyalty forming patterns. The author did not identify a similar survey conducted on the Polish tourism market on a sample of young adults.

\subsection{Destination loyalty intention}

Loyalty intention toward tourism destinations has been a subject of research and discussion for many authors. There have been numerous attempts to establish models of loyalty to tourist destinations [Kozak, 2001; Oom do Valle et al., 2006; Chi, 2011; Emir et al., 2016; Su et al., 2017; Ribeiro et al., 2018]. Most authors agree on the importance of satisfaction as a key driving factor of loyalty intentions [Duman and Mattila, 2005; Oom do Valle et al., 2006; Chi, 2011; Sabiote et al., 2012; Su et al., 2017; Ribeiro et al., 2018]. Researchers investigating reasons for choosing destinations identified a list of push and pull factors that can increase or decrease loyalty behavior, such as desire to escape, variety seeking, social factors, health recovery, need of rest, health recovery (push), tourist attractions, resources, local culture, local communities, services, shopping and entertainment opportunities, events, and tourist infrastructure (pull) [Kim, 2008; Mechinda et al., 2009; Sato et al., 2016; Wąsowicz-Zaborek, 2017].

The construct loyalty intention can be measured in different ways. In this research, after extensive literature studies, the author decided to use a framework of two main dimensions: re-visit intention (RVI) and recommendation intention (RI). Similar approach can be found in Oppermann [2000], Kozak and Rimmington [2000], Yoon and Uysal [2005], Oom do Valle et al. [2006], Chen and Tsai [2007], Rajesh [2013], Guzman-Parra et al. [2016], Su et al. [2017], and Chi and Qu [2008]. 


\subsection{Risk and uncertainty perception (RUP)}

A major factor in the choice of destination, crucial for research on risks and uncertainties, is the difficulty for tourists to anticipate or imagine the situation at a destination before travelling and therefore having to rely on information from sources such as media, friends, relatives, and tourist organizations [Karl, 2018].

Uncertainty avoidance is not the same as risk avoidance [Hofstede, 2011]. Uncertainty is vague and defies calculation, while risk is quantifiable and thus can be considered more consciously. Perception of risk accompanies almost all purchasing decisions through the assessment of benefits and costs connected with the purchase. One way to reduce risk is searching for and collecting information related to purchases, which may lead to increased loyalty to a brand if the choice made was satisfactory. Perceived risk is often an essential factor discouraging from changing the supplier of a product [Lee and Cunningham, 2001]. Perceived risk is established in literature as a potent determinant in the decision-making process of tourists. It is owing to the characteristics of the tourist product, such as its complexity, intangibility, and inseparability of its consumption and creation. Researchers identify several dimensions of risk in tourism: 1) physical, 2) functional, 3) psychological, 4) social, 5) temporal/time, 6) financial, and 7) overall (e.g. Boksberger and Craig-Smith [2006], Fuchs and Reichel [2008], and Çetinsöz and Ege [2013]). Owing to the general nature of this current research and the lack of reference to any specific destination in the survey, the overall dimension and its indicators were used for measurement.

Perceived risk related to the choice of a tourism destination may be considerable. An unknown and never visited before destination can be difficult to assess, and thus, the level of uncertainty will be high. In consequence, choosing a well-known destination decreases uncertainty and the perceived risk becomes lower. This close relationship between the concepts of risk and uncertainty and their similar influence on purchasing behavior, as indicated in the literature, led the author to decide to merge the two constructs into one. Hence, the following hypotheses were proposed:

H.1 RUP has a positive impact on RI

H.2 RUP has a positive impact on RVI

\subsection{Novelty and variety seeking}

The search for variety is an internally motivated behavior, where a change in one's everyday routine is rewarded with a sense of satisfaction [Niininen and Riley, 2008]. For some people, a daily routine may lead to low stimulation and boredom. Thus, a trip to a new place has a high stimulation potential and can increase one's level of satisfaction [Bello and Etzel, 1985]. Variety seeking may also manifest itself in traveling to places visited before, but to spend time differently by participating in other activities than previously.

Novelty seeking is the difference between a current perception and past experiences. This implies a desire to take physical, psychological, and social risks for the sake of diverse, new and sophisticated experiences [Coudounaris and Sthapit, 2017]. Novelty seeking is particularly important in tourism as it is an important motivation for travel [Duman and Mattila, 2005] and it is an innate feature of some travelers [Lee and Crompton, 1992]. The novelty seeking construct developed by Lee and Crompton [1992] consists of change from routine, thrill, surprise, and boredom alleviation.

It can be assumed that tourists motivated by the search for novelty or variety are less likely to visit the same destinations again because such trips will not provide them with sufficient excitement and therefore are boring and can be associated with a waste of time and money. However, being very satisfied with a new trip can make them more willing to recommend the visited place. Thus, the author hypothesizes:

H.3 NVS has a positive impact on RI

H.4 NVS has a negative impact on RVI 


\subsection{Social bonding}

Low and Altman [1992] note that SB relates to social relationships among individuals, between individuals and communities, and individuals and culture. SB is a construct that is primarily of interest to the literature in the field of environmental psychology as one of proposed dimensions of the place attachment concept [Kyle et al., 2005; Saxena, 2006; Chen et al., 2014]. As place attachment may be a very significant factor influencing tourist destination choice, SB has recently become a more commonly studied construct in the tourism literature [Kyle et al., 2005; Seweryn, 2013].

Strong social relations can lead to strong emotional ties to places, and these emotions are often the product of repetitive interactions and experiences that shape sentiment [Kyle and Chick, 2007]. As a consequence, social relations may cause higher RVI. Furthermore, increasing emotional involvement may influence the willingness to share information about the place to which a tourist is attached. Accordingly, it is possible to posit:

H.5 SB has a positive impact on $R I$

H.6 SB has a positive impact on RVI

\section{Conceptual framework and research methods}

Having identified the research gap, the author decided to conduct a survey to collect data from Generation Y members to test the six research hypotheses.

In this study, the author models the relationships between destination loyalty dimensions and their antecedents with a framework that involves five composite variables (or constructs): 1) RUP, 2) NVS, 3) SB, 4) RI, and 5) RVI. The links among the variables and pertinent hypotheses are illustrated in Figure 1.

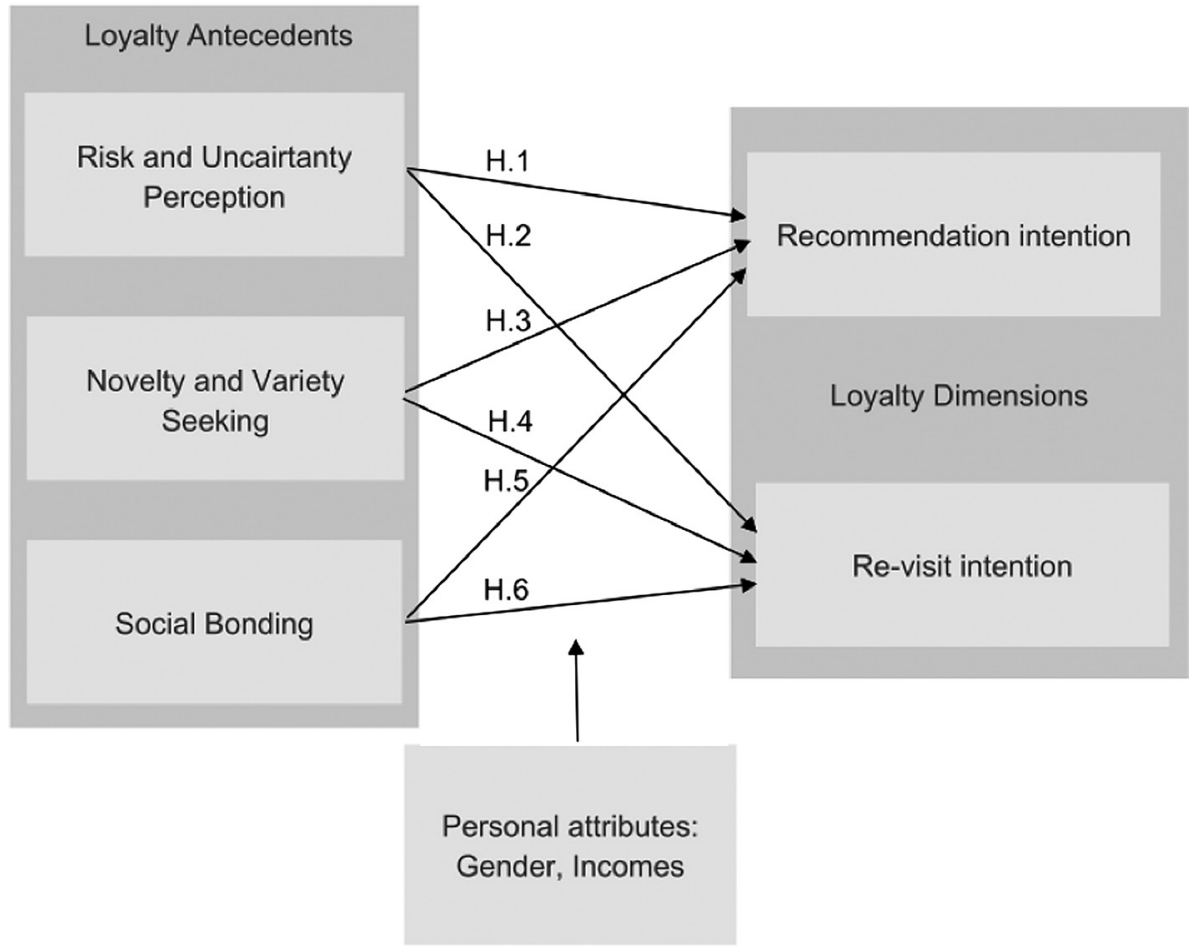

Figure 1. Conceptual model and hypotheses of the study.

Source: own elaboration. 
The model indicates that motivations and attitudes of tourists may influence their loyalty behavior. The research purposefully omits the specific features of the visited destination and the tourist's satisfaction with the stay, which are most frequently studied by other researchers in the context of loyalty. The author's intention was to determine general factors that might be important when returning to or recommending a destination, having more to do with individual attributes of the tourist rather than the specifics of a particular destination.

In order to collect empirical data, an Internet questionnaire was used. It was divided into three parts. The first part included questions about previous tourist experiences and motivation for travels. Questions in this part were constructed using nominal and Likert scales. The second part of the questionnaire referred to the tendency to revisit and to share opinions about the visited place, as well as the reasons for (not) returning to the visited places. Questions were designed with the use of Likert scales. Likert statements used for measuring the constructs are presented in Table 4. The questionnaire concluded with demographical items.

The survey was conducted on a group of 305 respondents recruited from the students of the SGH Warsaw School of Economics and the WSB University in Gdańsk from October 2018 to April 2019. All respondents were aged 18-32 years. Groups of students are a common subject of research in the tourism sector (e.g. Michael et al., 2003; Gallarza and Saura, 2006; Kim et al., 2006; Xu et al., 2009; Kim and Park, 2016). This is because this group of young adults is very active in tourism and involved in many tourist trips. It is partly because they have more free time to spend on traveling. They are also involved in many different tourism activities, e.g. active, cultural, educational, and leisure tourism. So, their experiences are very differentiated and potentially interesting for researchers. In addition, most students are unmarried and have no children, which allows them to make purchasing decisions based on their own preferences and likes, without the need to adjust to the needs of other family members. Thus, it can be assumed that the opinions expressed in the research reflect their own needs and not those shaped by the circumstances they find themselves in.

Table 1 describes demographical characteristics of the sample.

Because of a filter question at the beginning of the questionnaire, all respondents had traveled for tourist purposes at least once in the five years preceding the interview. The vast majority declared traveling both in Poland and abroad (89.2\%). A total of 5.6\% of respondents traveled only abroad, while $5.2 \%$ visited only Polish destinations.

Table 1. Descriptive Summary of the Sample $(n=305)$

\begin{tabular}{lrr}
\hline Demographic & $\mathbf{n}$ & $\%$ \\
\hline Gender & & \\
Female & 187 & $61,3 \%$ \\
Male & 118 & $38,7 \%$ \\
Size of the place of living & & \\
village & 18 & 5,9 \\
town up to 50 K & 15 & 4,9 \\
town 51-150 K & 15 & 4,9 \\
City 151 - 500 K & 20 & 6,6 \\
City more than 500 K & 237 & 77,7 \\
Work or Study & & \\
student & 208 & 68,2 \\
working student & 97 & 31,8 \\
Income & & \\
very low (difficult to cover maintenance costs) & 4 & 1,3 \\
low & 32 & 10,5 \\
moderate & 156 & 51,1 \\
high & 93 & 30,5 \\
very high & 20 & 6,6 \\
\hline
\end{tabular}

Source: own elaboration 
The initial statistical analysis was performed using SPSS 25. In the second phase, to explore regression paths among variables, SmartPLS 3.2.8 was used.

\section{Research results}

It seems that out of the two dimensions of destination loyalty, respondents are more likely to share opinions (both positive and negative) about visited places than to return to them (see Table 2). This may be related to the popularity of Internet tools and social media among Generation Y, and social media are among the most commonly used channels for sharing opinions about trips and destinations [TripAdvisor, 2016].

Regarding frequency of travel to the same places and not returning to previously visited ones, the average level of indications was similar and relatively low (2.18 and 2.32, respectively; there were no statistically significant differences between the mean values). This should be interpreted as a lack of a dominant preference in this regard - somewhat surprisingly, the young people were equally likely to travel to the same locations as new ones.

What is more, the respondents did not consider traveling to familiar places as overly boring (2.69). Curiosity about new destinations probably limits the tendency to return to those already visited, but with the mean value of 3.08, this is not a very strong sentiment. On the other hand, respondents recognized traveling to well-known places as somewhat less risky (3.09) but rather did not agree with the opinion that visiting a new place may be stressful (2.06) (see Table 3).

Table 2. Mean, maximum, minimum, and median values for answers concerning recommendation intention and revisit intention

\begin{tabular}{|c|c|c|c|c|c|}
\hline Items & Minimum & Maximum & Mean & $\begin{array}{l}\text { Standard } \\
\text { deviation }\end{array}$ & Median \\
\hline I return to visited destinations, but usually after a long time (a few years) & 1 & 5 & 3.16 & 0.923 & 3.0 \\
\hline I mostly travel to the same destinations & 1 & 5 & 2.18 & 0.797 & 2.0 \\
\hline I never return to destinations I have visited before & 1 & 5 & 2.32 & 1.005 & 2.0 \\
\hline I am willing to share negative opinions about the destinations I visit & 1 & 5 & 4.03 & 0.976 & 4.0 \\
\hline I am willing to share positive opinions about the destinations I visit & 1 & 5 & 4.57 & 0.762 & 5.0 \\
\hline If I liked the destination, I encourage other people to visit it & 1 & 5 & 4.54 & 0.786 & 5.0 \\
\hline
\end{tabular}

Source: own elaboration.

1 - strongly disagree and 5 - strongly agree.

Table 3. Mean, maximum, minimum, and median values for the answers concerning risk and uncertainty perception, novelty and variety seeking, and social bonding

\begin{tabular}{|c|c|c|c|c|c|}
\hline Items & Minimum & Maximum & Mean & $\begin{array}{l}\text { Standard } \\
\text { deviation }\end{array}$ & Median \\
\hline $\begin{array}{l}\text { If I were to visit the same destinations, it is because I am curious how } \\
\text { the place and people have changed }\end{array}$ & 1 & 5 & 2.84 & 0.991 & 3.0 \\
\hline I return to a destination I have already visited to show it to other people & 1 & 5 & 3.30 & 1.077 & 4.0 \\
\hline $\begin{array}{l}\text { I return to the previously visited place for people who are living there } \\
\text { (family, friends, acquaintances) }\end{array}$ & 1 & 5 & 3.32 & 1.181 & 4.0 \\
\hline I like to spend my holidays in a familiar place & 1 & 5 & 3.23 & 0.987 & 3.0 \\
\hline Traveling to the same places is less risky & 1 & 5 & 3.09 & 1.092 & 3.0 \\
\hline Visiting new places is stressful & 1 & 5 & 2.06 & 1.051 & 2.0 \\
\hline Traveling to destinations already visited is a waste of money & 1 & 5 & 1.99 & 0.970 & 2.0 \\
\hline $\begin{array}{l}\text { There are so many places to see that I do not have time to visit the same } \\
\text { destinations again }\end{array}$ & 1 & 5 & 3.08 & 1.216 & 3.0 \\
\hline Traveling to the same places is boring & 1 & 5 & 2.69 & 1.140 & 3.0 \\
\hline
\end{tabular}

Source: own elaboration.

1 - strongly disagree and 5 - strongly agree. 
The main statistical method for testing the research hypotheses was a structural model estimated by the partial least squares (PLS) method. According to the best practices outlined in the literature, the first step in investigating a partial PLS model is to establish the quality of the so-called measurement model, which defines relationships between latent constructs and their indicators.

According to the procedures recommended by Hair et al. [2017], the metrics for average variance extracted (AVE) and composite reliability (CR) were calculated in order to verify the correctness of the investigated constructs (Table 4). For each factor, CR was greater than 0.7 and AVE exceeded the 0.5 threshold. These figures, combined with the absolute values of factor loadings exceeding 0.6, demonstrate the high reliability of all the extracted factors [Hair et al., 2017].

For further confirmation of the quality of the constructs, discriminant validity was investigated to check if sufficient differences exist between latent variables. Fornell and Larcker [1981] suggested that discriminant validity could be established when the square root of AVE for each construct is higher than the correlation coefficients between the focal construct and all the other constructs in the model (Table 5). Since all the correlations are smaller than the square roots of AVEs, it can be concluded that all latent variables show appropriate separation from each other and there are no big overlaps in their meaning.

To provide additional insights about the quality of the model, Stone-Geisser's $Q^{2}$ metrics were computed for the two endogenous constructs, using the blindfolding procedure with an omission distance of 7 . Their respective values for RVI and RI were both positive and equal to 0.196 and 0.061 , respectively, which point to predictive relevance of the structural model [Hair et al., 2016, p. 212].

Table 4. Indicators of construct variables in the study

\begin{tabular}{|c|c|c|c|c|}
\hline Indicators & $\begin{array}{l}\text { Sources of scale } \\
\text { indicators }\end{array}$ & $\begin{array}{l}\text { Factor } \\
\text { loadings }\end{array}$ & $\begin{array}{l}\text { Composite } \\
\text { reliability }\end{array}$ & $\begin{array}{l}\text { Average } \\
\text { variance } \\
\text { extracted }\end{array}$ \\
\hline Risk and uncertainty perceptions (RUPs) & & & 0.833 & 0.625 \\
\hline RUP 1. Visiting new places is stressful & Boksberger and Craig- & 0.740 & & \\
\hline RUP 2. Traveling to the same places is less risky & Smith [2006]; Fuchs & 0.748 & & \\
\hline RUP 3. I like to spend my holidays in a familiar place & and Reichel [2008] & 0.877 & & \\
\hline Novelty and variety seeking (NVS) & & & 0.858 & 0.669 \\
\hline NVS 1. Traveling to the same places is boring & Lee and Crompton & 0.811 & & \\
\hline $\begin{array}{l}\text { NVS } 2 \text {. There are so many places which I want to see that I do not } \\
\text { have time to visit the same destinations again }\end{array}$ & $\begin{array}{l}\text { [1992]; Kim and Kim } \\
\text { [2015] }\end{array}$ & 0.853 & & \\
\hline $\begin{array}{l}\text { NVS } 3 . \text { I would prefer to spend my money for visiting new places } \\
\text { than the already known }\end{array}$ & & 0.787 & & \\
\hline Social bonding (SB) & & & 0.812 & 0.598 \\
\hline $\begin{array}{l}\text { SB } 1 . \text { I return to the previously visited place for people who are } \\
\text { living there (family, friends, acquaintances) }\end{array}$ & $\begin{array}{l}\text { Jang et al. [2009]; } \\
\text { Luo and Hsieh [2013]; }\end{array}$ & 0.653 & & \\
\hline $\begin{array}{l}\text { SB } 2 . \text { I return to a destination I have already visited to show it to } \\
\text { other people }\end{array}$ & Kyle et al. [2005] & 0.958 & & \\
\hline $\begin{array}{l}\text { SB. } 3 \text { If I were to visit the same destinations, it is because I am } \\
\text { curious how the place and people have changed }\end{array}$ & & 0.653 & & \\
\hline Recommendation intention (RI) & & & 0.864 & 0.684 \\
\hline RI 1. If I liked the destination, I encourage other people to visit it & Alexandrov et al. & 0.895 & & \\
\hline $\begin{array}{l}\text { RI 2. I am willing to share positive opinions about the } \\
\text { destinations I visit }\end{array}$ & $\begin{array}{l}\text { [2013]; Chi and Qu } \\
\text { [2008] }\end{array}$ & 0.902 & & \\
\hline $\begin{array}{l}\text { RI 3. I am willing to share negative opinions about the } \\
\text { destinations I visit }\end{array}$ & & 0.661 & & \\
\hline Revisit intention (RVI) & & & 0.771 & 0.619 \\
\hline RVI 1. I never return to destinations I have visited before & Luo and Hsieh [2013]; & -0.875 & & \\
\hline RVI 2. I mostly travel to the same destinations & Kozak [2001]; & 0.802 & & \\
\hline $\begin{array}{l}\text { RVI 3. I return to visited destinations, but usually after a } \\
\text { long time (a few years) }\end{array}$ & $\begin{array}{l}\text { Bello and Etzel [1985]; } \\
\text { Chi and Qu [2008] }\end{array}$ & 0.670 & & \\
\hline
\end{tabular}

Source: own elaboration. 
Table 5. Discriminant validity of latent variables according to Fornell-Locker criteria: Square roots of average variances extracted and correlations between all pairwise combinations of latent variables

\begin{tabular}{lccccc}
\hline Social bonding (SB) & $\begin{array}{c}\text { Novelty and variety } \\
\text { seeking (NVS) }\end{array}$ & $\begin{array}{c}\text { Revisit intention } \\
\text { (RVI) }\end{array}$ & $\begin{array}{c}\text { Recommendation } \\
\text { intention (RI) }\end{array}$ & $\begin{array}{c}\text { Risk and uncertainty } \\
\text { perception (RUP) }\end{array}$ \\
\hline SB & 0.773 & & & & \\
NVS & -0.070 & 0.818 & & & \\
RVI & 0.085 & -0.573 & 0.787 & & \\
RI & 0.230 & 0.019 & 0.052 & 0.827 & \\
RUP & 0.152 & -0.264 & 0.329 & 0.077 & 0.791 \\
\hline
\end{tabular}

Source: own elaboration.

An extension of $R^{2}$ values are $f^{2}$ coefficients that capture changes in $R^{2}$ when specific exogenous constructs are omitted from the model, drawing on the drop in $R^{2}$ before and after the omission. The metric is standardized with three recommended thresholds conventionally used for interpretation [Cohen, 1988]: 0.02 (small effect), 0.15 (medium effect), and 0.35 (large effect). In the current analysis, the strongest effect found was the link between novelty seeking and RVI $\left(f^{2}=0.391\right)$. Other predictors, showing small but significant effects, were found for the regression paths: risk and uncertainty avoidance - RVI $\left(f^{2}=0.050\right)$, emotional solidarity $-\mathrm{RI}\left(f^{2}=0.052\right)$, incomes $-\mathrm{RI}\left(f^{2}=0.023\right)$, and incomes ${ }^{\star}$ risk and uncertainty avoidance RI (moderating effect, $f^{2}=0.035$ ).

Even though the main object of the PLS method is maximizing the predictive accuracy of endogenous constructs, and not - unlike the covariance-based structural equation modeling (CB SEM) - minimizing errors between empirical and model-implied covariance matrices, it is useful to see how well a PLS model performs in this regard. Accordingly, if it shows small errors (residuals) between the empirical and theoretical covariance matrixes, it can be assumed to not only work well as a predictive tool but also to accurately reflect hypothesized relationships embedded into the model. To this end, one can use the metrics of standardized root mean square residuals (SRMR) and root mean square residual covariances (RMS theta). It is generally considered that for CB SEM, a good fit with empirical data is indicated by SRMR $<0.08$ and RMS theta $<0.12$. At the moment of this writing, there were no widely acceptable thresholds for PLS SEMs, but many researchers were in agreement that the values of 0.08 and 0.12 were too restrictive [Henseler et al., 2015; Hair et al., 2016, p. 204]. In the current study, the coefficients of SRMR and RMS theta were almost exactly at the cutoff point ( 0.083 and 0.189 , respectively), which corroborates the adequate quality of the analytical framework.

Once the quality of the measurement model was found acceptable, standard regression weights and $p$-values between constructs in the structural model were used to test the hypotheses (Table 6).

From Table 6 three estimated regression paths were statistically significant, which gives support to three hypotheses: H.2, H.4, and H.5.

Specifically, there is a statistically significant relationship between RUP and RVI. The greater the RUP level, the more tourists are likely to return to the places they have already visited.

The standardized regression weight values for NVS and RVI indicate a negative correlation, which means that higher levels of NVS tend to coincide with a lower inclination to revisit already known places.

The analysis also shows that RI is significantly influenced by SB so that higher SB levels are linked to greater RI.

To account for the possibility of dissimilar regression patterns in distinct demographical groups, the author investigated possible moderation effects of the focal relationships with gender and income. The significance tests for all possible two-way interactions showed that males and females are no different in terms of the investigated regression weights. Indeed, the only significant moderation effect was found for income and the way it affects the association between RUP and RI. It transpired that for average levels of income, RUP and RI are not significantly correlated. However, for very large and very small incomes (about 
Table 6. Regression weights and $p$-values for estimated path models

\begin{tabular}{|c|c|c|c|}
\hline Hypotheses & Regression paths & $\begin{array}{l}\text { Standardized Sample } \\
\text { Regression Weights }\end{array}$ & $\begin{array}{c}\text { Bootstrapping* } \\
\text { p-values }\end{array}$ \\
\hline H.1 & RUP $->$ RI & 0,086 & 0.224 \\
\hline H.2 & RUP -> RVI** & 0,187 & 0.010 \\
\hline H.3 & NVS -> RI & 0,036 & 0.561 \\
\hline H. 4 & NVS -> RVI** & $-0,526$ & 0.004 \\
\hline H.5 & $\mathrm{SB}->\mathrm{RI}^{\star \star}$ & 0,231 & 0.000 \\
\hline H.6 & $\mathrm{SB}$-> RVI & 0,019 & 0.734 \\
\hline \multicolumn{4}{|c|}{ Regression terms for significant controlled variables } \\
\hline & Main Effect: Incomes -> RI** & 0,145 & 0,010 \\
\hline & Moderating Effect: Incomes - RUA -> RI & $-0,168$ & 0,004 \\
\hline
\end{tabular}

Source: own elaboration.

*Based on 5000 subsamples.

${ }^{*}$ Significant values at the 0.05 level.

2 standard deviations from the mean), RUP has a significant influence on RI. Interestingly, the direction of the relationship is not constant and is positive for respondents with low incomes and negative for those with high earnings. This moderating effect of income provides partial support for hypothesis H.1, which can be deemed validated for those tourists whose incomes are substantially lower than the average. In this group, RUP has a positive impact on RI.

To conclude this overview of the research results, it should be noted that the estimated structural model explained $11.1 \%$ of variance in RI and $36.4 \%$ of variance in RVI. The diagram of regression paths between research constructs is presented in appendix (see Figure A.1 in Appendix).

\section{Conclusions and limitations of the study}

The aim of the study was to address the existing research gap concerning the loyalty to tourist destinations of young adults. The hypotheses and the conceptual model were developed from previous research by other authors, in particular the works by Kozak [2001], Boksberger and Craig-Smith [2006], Kyle et al. [2005], Chi and Qu [2008], and Kim and Kim [2015]. The unique aspect of the study was investigating loyalty intentions in general and not toward a particular place, as was the case in most previous research.

The study demonstrates that members of Generation Y are split between the willingness to travel to familiar places and getting to know new destinations. It seems that a factor that can be a potent influence on them in trying to encourage loyalty behavior is SB. It was found that the social context represented by SB has a significant positive impact on RI. Han et al. [2019] in their research on community-based tourism came to a similar conclusion. Although a broader context of the sense of belonging was analyzed, of which $\mathrm{SB}$ is one aspect, it was observed that higher levels of this category correspond with a greater willingness to make recommendations.

In the present research, traveling to new destinations is not generally perceived as a stressful situation, but RUP is not a negligible factor and could play a role in consumer decisions. This was validated by a significant positive regression link demonstrating that high uncertainty and risk association with new places can lead to the choice of well-tested destinations. Rittichainuwat and Chakraborty [2009] also found that tourists may be less interested in destinations with high-risk perceptions. On the other hand, it should be stressed that the most important discouraging factor from visiting the same place is NVS. Similar observations can be found in Kim and Kim [2015], who report that novelty seeking decreases the overall level of satisfaction with travel and thus reduces the tendency to revisit. 
An interesting finding was the role of income in the investigated conceptual framework. It turns out that the tourist's income should be considered in anticipating their intentions to recommend familiar destinations. This effect is twofold: first, there is a significant positive main effect of the income variable, implying that those with higher incomes are more willing to share opinions with all the other variables kept constant (ceteris paribus rule). Second, there was a significant moderating effect of income on the regression path from RUPs to RIs. If an individual's level of perceived risk and uncertainty is high, those with low incomes will share their opinions more willingly, while more affluent young tourists will demonstrate the opposite tendency.

The moderating influence of gender on factors affecting loyalty intentions has not been confirmed. Apparently, there are no differences between young men and women in terms of the explored processes leading to the formation of loyalty intentions. This might suggest that when catering to Millennials, tourist offers do not have to be differentiated by gender. A similar conclusion was reached by Chi et al. [2009] who concluded that male and female tourists displayed comparable loyalty toward the destination analyzed by them.

It should be stressed, however, that the author's study did not investigate destination preferences of tourists in depth. So even though factors like RUPs seem to work in the same way for both genders, the specifics of what attributes of a tourism destination make it more risky or exciting could be different for males and females. This is one of the limitations of this study and also a suggestion for further research.

This study has a number of limitations. First, the collected sample allows to generalize findings to the populations of students from only two Polish universities located in two large urban centers of the country. The findings from a broader sample, encompassing universities in other parts of Poland, especially in less populous areas may give different results. Also, the Millennials from countries other than Poland could possibly yield different results. One of the possible directions for future research could be a comparison of different generation cohorts to see if the same factors contribute to loyalty intentions. In addition, the study could benefit from the inclusion of other control variables, to better model interpersonal differences between respondents; as a result, new interesting interaction patterns could be revealed. A replication of the study in other country settings could demonstrate if the relationships found here are only specific to Poland or could be considered universal for the whole Generation Y.

The developed model can be used as a guide for tourist enterprises and institutions managing tourist destinations to prepare more successful products and more effective promotional initiatives. For example, when preparing a tourist offer for young adults who are familiar with the destination from previous visits, it is advisable to introduce new activities in response to their expectation of variety and novelty. Because of the significance of RUP, it is instrumental to design marketing communications so that they provide sufficiently exhaustive and persuasive information to lower this sentiment. The important role played by SB points to possibly effective tropes and motives in the content of promotional campaigns, as well as suggests that social media could be a viable communication channel. To further leverage the positive effects of SB, social media could be used to create online communities around tourist destinations to foster loyalty intentions.

\section{References}

Alexandrov, A., Lilly, B., Babakus, E. (2013), The effects of social- and self-motives on the intentions to share positive and negative word of mouth, Journal of the Academy of Marketing Science, Vol. 41, No. 5, pp. 531-546.

Artuger, S., Cetinsoz, B.C. (2017), The impact of destination image and the intention to revisit: a study regarding Arab tourists, European Scientific Journal, ESJ, Vol. 13, No. 5, p. 82.

Assaker, G., Hallak, R. (2013), Moderating effects of tourists' novelty-seeking tendencies on destination image, visitor satisfaction, and short- and long-term revisit intentions, Journal of Travel Research, Vol. 52, No. 5, pp. 600-613.

Backman, S.J., Crompton, J.L. (1991), The usefulness of selected variables for predicting activity loyalty, Leisure Sciencesiences, Vol. 13, No. 3, pp. 205-220.

Bello, D.C., Etzel, M.J. (1985), The role of novelty in the pleasure travel experience, Journal of Travel Research, Vol. 24, No. 1, pp. 20-26.

Bigne, J., Sanchez, M., Sanchez, J. (2001), Tourism image, evaluation variables and after purchase behavior: interrelationship, Tourism Management, Vol. 22, pp. 607-616. 
Boksberger, P.E., Craig-Smith, S.J. (2006), Customer value among tourists: a conceptual framework and a risk-adjusted model, Tourism Review, Vol. 61, No. 1, pp. 6-12.

Bowen, D. (2001), Antecedents of Consumer Satisfaction and Dis-satisfaction(CS/D) on long-haul inclusive tours: a reality check on theoretical considerations, Tourism Management, Vol. 22, pp. 49-61.

Çetinsöz, B.C., Ege, Z. (2013), Impacts of perceived risks on tourists' revisit intentions, Anatolia, Vol. 24, No. 2, pp. 173-187.

Chen, C.F., Tsai, D.C. (2007), How destination image and evaluative factors affect behavioral intentions? Tourism Management, Vol. 28, No. 4, pp. 1115-1122.

Chen, J.S., Gursoy, D. (2001), An investigation of tourists' destination loyalty and preferences, International Journal of Contemporary Hospitality Management, Vol. 13, No. 2, pp. 79-85.

Chen, N. (Chris), Dwyer, L., Firth, T. (2014), Conceptualization and measurement of dimensionality of place attachment, Tourism Analysis, Vol. 19, No. 3, pp. 323-338.

Chi, C.G.-Q. (2011), Destination loyalty formation and travelers' demographic characteristics: a multiple group analysis approach, Journal of Hospitality and Tourism Research, Vol. 35, No. 2, pp. 191-212.

Chi, C.G.-Q., Gursoy, D., Qu, H. (2009), Demographic variables and loyalty formation: a systematic examination, in: International CHRIE Conference-Refereed Track. 18.

Chi, C.G.-Q., Qu, H. (2008), Examining the structural relationships of destination image, tourist satisfaction and destination loyalty: an integrated approach, Tourism Management, Vol. 29, No. 4, pp. 624-636.

Cohen, J. (1988), Statistical power analysis for the behavioral sciences, Lawrence Erlbaum, Mahwah, NJ.

Coudounaris, D.N., Sthapit, E. (2017), Antecedents of memorable tourism experience related to behavioral intentions, Psychology and Marketing, Vol. 34, No. 12, pp. 1084-1093.

Day, G. (1969), A two-dimensional concept of brand loyalty, Journal of Advertising Research, 9, pp. 9-35.

Duman, T., Mattila, A.S. (2005), The role of affective factors on perceived cruise vacation value, Tourism Management, Vol. 26, No. 3, pp. 311-323.

Dziedzic, E., Skalska, T. (2012), Ekonomiczne uwarunkowania rozwoju usług turystycznych w Polsce. Stowarzyszenie na Rzecz Badania, Rozwoju i Promocji Turystyki, Warszawa.

Emir, O., Saracli, S., Bayer, R.U., Artuğer, S. (2016), Modelling tourist loyalty via statistical techniques, Turizam, Vol. 20, No. 2, pp. 49-60.

Farley, J.U. (1964), Why does "brand loyalty" vary over products? Journal of Marketing Research, Vol. 1, No. 4, pp. 9-14.

Fornell, C., Larcker, D.F. (1981), Evaluating structural equation models with unobservable variables and measurement error, Journal of Marketing Research, Vol. 18, No. 1, pp. 39-50.

Fornell, C., Wernerfelt, B. (1987), Defensive marketing strategy by customer complaint management: a theoretical analysis, Journal of Marketing Research, Vol. 24, No. 4, pp. 337-346.

Foscht, T., Maloles, C. III, Chia, S.L. Department. (2009), Assessing the outcomes of generation-Y customers' loyalty, International Journal of Bank Marketing, Vol. 27, No. 3, pp. 218-241.

Fuchs, G., Reichel, A. (2008), Tourist destination risk perception: the case of Israel, Journal of Hospitality \& Leisure Marketing, Vol. 14, No. 2, pp. 83-108.

Gallarza, M.G., Saura, I.G. (2006), Value dimensions, perceived value, satisfaction and loyalty: an investigation of university students' travel behaviour', Tourism Management, 27, pp. 437-452.

George, B.P., George, B.P. (2004), Past visits and the intention to revisit a destination: place attachment as the mediator and novelty seeking as the moderator, Journal of Tourism Studies, Vol. 15, No. 2, pp. 51-66, retrieved from http://www. cabdirect.org/abstracts/20053022778.html.

Gołąb-Andrzejak, E. (2014), Lojalność eurokonsumentów pokolenia Y, Handel Wewnętrzny, Vol. 1, No. 354, pp. $110-119$.

Gołąb-Andrzejak, E. (2016), Konsumenci pokolenia Y - nowe wyzwanie dla komunikacji marketingowej, Handel Wewnętrzny, Vol. 2, No. 361, pp. 140-151

Guzman-Parra, V.F., Vila-Oblitas, J.R., Maqueda-Lafuente, F.J. (2016), Exploring the effects of cognitive destination image attributes on tourist satisfaction and destination loyalty: a case study of Málaga, Spain, Tourism \& Management Studies, Vol. 12, No. 1, pp. 67-73.

Hair, J.F. Jr., Hult, G.T.M., Ringle, C., Sarstedt, M. (2016), A primer on partial least squares structural equation modeling (PLS-SEM), 2nd edn, Sage, Thousand Oaks, p. 204.

Hair, J.F. Jr., Hult, G.T.M., Ringle, C.M., Sarstedt, M. (2017), A primer on partial least squares structural equation modeling (PLS-SEM), Sage Publications Inc., Thousand Oaks, pp. 138-140.

Han, H., Eom, T., Al-Ansi, A., Ryu, H.B., Kim, W. (2019), Community-based tourism as a sustainable direction in destination development: an empirical examination of visitor behaviors, Sustainability (Switzerland), Vol. 11, No. 10, p. 2864.

Henseler, J., Hubona, G., Ray, P. (2015), Using PLS path modeling in new technology research: updated guidelines, Industrial Management and Data Systems, Vol. 116, No. 1, pp. 2-20.

Hofstede, G. (2011), Dimensionalizing cultures: the Hofstede model in context, retrieved from Online Readings in Psychology and Culture, Vol. 2, No. 1, doi.:10.9707/2307-0919.1014.

Howe, N., Strauss, W. (2007), The next 20 years: how customer and workforce attitudes will evolve, Harvard Business Review, Vol. 85 , No. 7/8, pp. 41-52. 
Hsu, C.H. (2000), Determinants of mature travels' motor-coach tour satisfaction and brand loyalty, Journal of Hospitality \& Tourism Research, 24, 223-238.

Huang, S., Hsu, C.H.C. (2009), Effects of travel motivation, past experience, perceived constraint, and attitude on revisit intention, Journal of Travel Research, Vol. 48, No. 1, pp. 29-44.

Jacoby, J., Kyner, D.B. (1973), Brand loyalty vs. repeat purchasing behavior, Journal of Marketing Research, Vol. 10, No. 1, pp. 1-9.

Jang, S., Bai, B., Hu, C., Wu, Ch-M.E. (2009), Affect, travel motivation, and travel intention: a senior market, Journal of Hospitality and Tourism Research, Vol. 33, No. 1, pp. 51-73.

Karl, M. (2018), Risk and uncertainty in travel decision-making: tourist and destination perspective, Journal of Travel Research, Vol. 57, No. 1, pp. 129-146.

Kim, A.K., Brown, G. (2012), Understanding the relationships between perceived travel experiences, overall satisfaction, and destination loyalty, Anatolia, Vol. 23, No. 3, pp. 328-347.

Kim, K. (2008), Analysis of structural equation model for the student pleasure travel market: motivation, involvement, satisfaction, and destination loyalty, Journal of Travel and Tourism Marketing, Vol. 24, No. 4, pp. 297-313.

Kim, K., Jogaratnam, G., Noh, J. (2006), Travel decisions of students at a US university: segmenting the international market, Journal of Vacation Marketing, Vol. 12, No. 4, pp. 345-357.

Kim, K.-H., Park, D.-B. (2016), Relationship among perceived value, satisfaction, and loyalty: community-based ecotourism in Korea, Journal of Travel and Tourism Marketing, pp. 1-21, doi:10.1080/10548408.2016.1156609.

Kim, S., Kim, H. (2015), Moderating effects of tourists' novelty-seeking tendencies on the relationship between satisfaction and behavioral intention, Tourism Analysis, Vol. 20, No. 5, pp. 511-522.

Kowalczyk-Anioł, J. (2012), Tendencje rozwoju turystyki polskiej młodzieży Pokolenia Y, Turyzm, Vol. 22, No. 2, pp. 15-21.

Kozak, M. (2001), Repeaters' behavior at two distinct destinations, Annals of Tourism Research, 28, pp. 784-807.

Kozak, M., Rimmington, M. (2000), Tourist satisfaction with Mallorca, Spain, as an Off-season holiday destination, Journal of Travel Research, 38, pp. 260-269.

Kyle, G., Graefe, A., Manning, R. (2005), Testing the dimensionality of place attachment in recreational settings, Environment and Behavior, Vol. 37, No. 2, pp. 153-177.

Kyle, G., Chick, G. (2007), The social construction of a sense of place, Leisure Sciences, Vol. 29, No. 3, pp. 209-225.

Lee, M., Cunningham, L.F. (2001), A cost/benefit approach to understanding service loyalty, Journal of Services Marketing, Vol. 15, No. 2, pp. 113-130.

Lee, T., Crompton, J. (1992), Measuring novelty seeking in tourism, Annals of Tourism Research, 19, pp. 732-751.

Low, S.M., Altman, I. (1992), Place attachment: a conceptual inquary, in: I. Altman, S.M. Low, (Eds), Place attachment, Plenum Press, New York and London, pp. 1-12. ISBN 978-1-4684-8755-8.

Luo, S.J., Hsieh, L.Y. (2013), Reconstructing revisit intention scale in tourism, Journal of Applied Sciences, Vol. 13, No. 18, pp. 3638-3648.

McConnell, J.D. (1968), The development of brand loyalty: an experimental study, Journal of Marketing Research, Vol. 5, No. 1, p. 13.

Mechinda, P., Serirat, S., Gulid, N. (2009), An examination of tourists' attitudinal and behavioral loyalty: comparison between domestic and international tourists, Journal of Vacation Marketing, Vol. 15, No. 2, pp. 129-148.

Meleddu, M., Paci, R., Pulina, M. (2015), Repeated behaviour and destination loyalty, Tourism Management, Vol. 50, pp. 159-171.

Michael, I., Armstrong, A., King, B. (2003), The travel behaviour of international students : the relationship between studying abroad and their choice of tourist destinations, Journal of Vacation Marketing, Vol. 10, No. 1, pp. 57-66.

Moscardo, G., Benckendorff, P. (2010), Mythbusting: generation Y and travel, in: P. Benckendorff, et al. (Eds), Tourism and Generation Y, CAB International, Wallingford, Oxfordshire, UK, pp. 16-26.

New Strategist. (2004), The millennials: Americans born 1977 to 1994, New Strategist Publications Inc., Ithaca, New York. Niininen, O., Riley, M. (2008), Towards the conceptualization of tourism destination loyalty, Tourism Analysis, Vol. 8, No. 2, pp. 243-246.

Oliver, R.L. (1997), Satisfaction: a behavioral approach, McGraw-Hill, Boston, p. 372.

Oliver, R.L. (1999), Whence customer loyalty, Journal of Marketing, Vol. 63, Special Issue, pp. 33-44.

Oom do Valle, P., Silva, J., Medeces, J., Guerreiro, M. (2006), Tourist satisfaction and destination loyalty intention: a structural and categorical analysis, International Journal of Business Science and Applied Management, Vol. 1, No. 1, pp. 25-44, retrieved from http://business-and-management.org/library/2006/1_1 - 25-44 - Oom_do_Valle,Silva,Mendes,Guerreiro. pdf.

Oppermann, M. (2000), Tourism destination loyalty, Journal of Travel Research, Vol. 39, pp. 78-84.

Rajesh, R. (2013), Impact of tourist perceptions, destination image and tourist satisfaction on destination loyalty: a conceptual model, PASOS, Revista de Turismo y Patrimonio Cultural, Vol. 11, No. 3, pp. 67-78.

Ramseook-Munhurrun, P., Seebaluck, V.N., Naidoo, P. (2015), Examining the structural relationships of destination image, perceived value, tourist satisfaction and loyalty: case of Mauritius, Procedia-Social and Behavioral Sciences, 175, pp. 252-259. 
Reichheld, F.F., Markey, R.G. Jr., Hopton, Ch. (2000), The loyalty effect - the relationship between loyalty and profits, European Business Journal, Vol. 12, No. 3, pp. 134-139.

Ribeiro, M.A., Woosnam, K.M., Pinto, P., Silva, J.A. (2018), Tourists' destination loyalty through emotional solidarity with residents: an integrative moderated mediation model, Journal of Travel Research, Vol. 57, No. 3, pp. 279-295.

Richard, K. Miller and Associates. (2011), Consumer behavior 2011: millennial consumers, Richard K. Miller and Associates (RKMA), Loganville, GA, pp. 211-216.

Richards, G. (2007), New horizons II: the young independent travellers 2007, WYSE Travel Confederation, Amsterdam.

Rittichainuwat, B.N., Chakraborty, G. (2009), Perceived travel risks regarding terrorism and disease: the case of Thailand, Tourism Management, Vol. 30, No. 3, pp. 410-418.

Sabiote, C.M., Frías, D.M., Castañeda, J.A. (2012), The moderating effect of uncertainty-avoidance on overall perceived value of a service purchased online, Internet Research, Vol. 22, No. 2, pp. 180-198.

Sato, S., Kimb, H., Buningc, R.J., Haradad, M. (2016), Adventure tourism motivation and destination loyalty: a comparison of decision and non-decision makers, Journal of Destination Marketing \& Management, (December), pp. 1-8. http://dx.doi. org/10.1016/j.jdmm.2016.12.003

Saxena, G. (2006), Beyond mistrust and competition - the role of social and personal bonding processes in sustaining livelihoods of rural tourism businesses: a case of the peak district national park, International Journal of Tourism Research, Vol. 8, pp. 263-277.

Seweryn, R. (2010), Lojalność turystów wobec obszaru recepcji (na przykładzie wyników badań ruchu turystycznego w Krakowie). Zeszyty Naukowe/Uniwersytet Ekonomiczny w Krakowie, Vol. 825, s. 21-37.

Seweryn, R. (2012), Lojalność odwiedzających wyzwaniem dla obszaru recepcji turystycznej w obecnych warunkach rynkowych, [w:] A. Rapacz, (red.), Wyzwania współczesnej polityki turystycznej. Problemy funkcjonowania rynku turystycznego, Prace Naukowe Uniwersytetu Ekonomicznego we Wroctawiu, nr 258, s. 24-34.

Seweryn, R. (2013), Rola lokalnych społeczności w kształtowaniu zadowolenia i lojalności turystów na przykładzie Krakowa. Zeszyty Naukowe Uniwersytetu Szczecińskiego nr 775, seria: Problemy Zarządzania, Finansów i Marketingu, 30. Szczecin: Wydawnictwo Naukowe US, 2013, s. 515-530.

Sheth, J.N. (1968), A factor analytical model of brand loyalty, Journal of Marketing Research, Vol. 5, No. 4, 395-404.

Su, L.J., Hsu, M.K., Swanson, S. (2017), The effect of tourist relationship perception on destination loyalty at a world heritage site in China: the mediating role of overall destination satisfaction and trust, Journal of Hospitality and Tourism Research, Vol. 41, No. 2, pp. 180-210.

Strum, D. L., Thiry, A., (1991), Building customer loyalty. Training \& Development Journal, Vol. 45, No. 4, pp. $34-36$.

Todorović, N., Jovičić, D. (2016), Motivational factors of youth tourists visiting Belgrade, Journal of the Geographical Institute “Jovan Cvijic”, SASA 2016, Vol. 66, No. 2, pp. 273-289.

TripBarometer. (2016), Traveler Trends \& Motivations Global Findings, Tripadvisor.

Um, S., Chon, K., Ro, Y. (2006), Antecedents of revisit intention, Annals of Tourism Research, Vol. 33, No. 4, pp. 1141-1158.

Wąsowicz-Zaborek, E. (2017), Użyteczność krańcowa a lojalność wobec miejsca docelowego. Prace naukowe uniwersytetu ekonomicznego we Wrocławiu. Prace Naukowe Uniwersytetu Ekonomicznego we Wrocławiu. Gospodarka turystyczna w regionie. Przedsiębiorstwo, samorząd wspótpraca, Vol. 473, pp. 578-596.

Worthington, S., Russell-Bennett, R., Hartel, Ch. E.J. (2009), A tri-dimensional approach for auditing brand loyalty, Journal of Brand Management, Vol. 17, No. 4, pp. 243-253.

Xu, F., Morgan, M., Song, P. (2009), Students' travel behaviour : a cross-cultural comparison of UK and China, International Journal of Tourism Research, Vol. 11, pp. 255-268.

Yoon, Y., Uysal, M. (2005), An examination of the effects of motivation and satisfaction on destination loyalty: a structural model, Tourism Management, Vol. 26, No. 1, pp. 45-56. 


\section{Appendix}

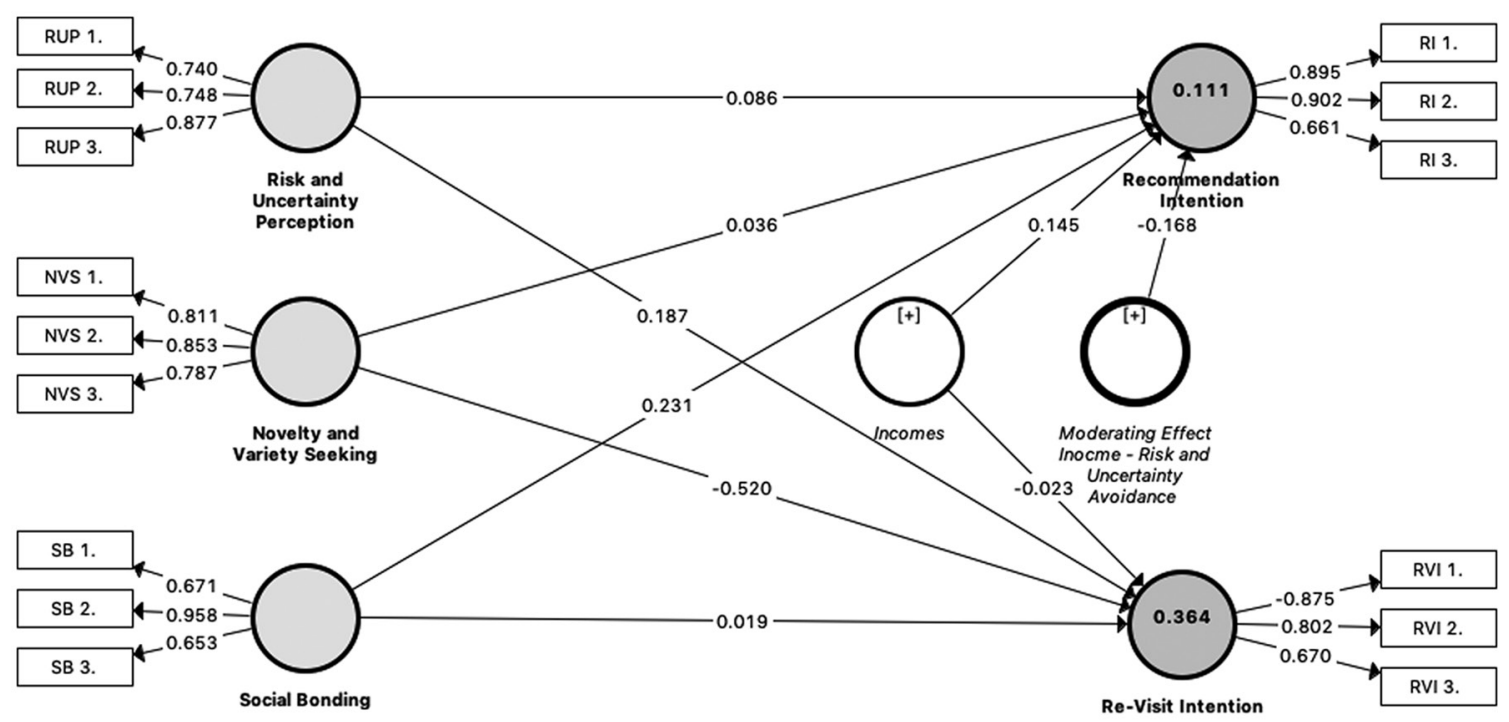

Figure A1. Structural equation model for antecedences for destination loyalty intention among young adults. Diagram of regression paths between research constructs.

Source: own elaboration. 